\title{
THE IMITATION MODEL OF BURSTY AND BATCH DATA PACKET FLOW
}

\author{
Aušra Žvironiené $\dot{1}^{1}, Z_{\text {Zenonas Navickas }}^{2}$, Ramutis Rindzevičius ${ }^{3}$ \\ Dept of Applied Mathematics, Kaunas University of Technology, \\ Studentug. 50, LT-51368 Kaunas, Lithuania \\ E-mails:.'Ausra.Zvironiene@ktu.lt, ${ }^{2} Z$ enonas.Navickas@ktu.lt, \\ ${ }^{3}$ Ramutis.Rindzevicius@ktu.lt
}

Received 15 June 2006; accepted 20 November 2006

\begin{abstract}
The imitation model of bursty and batch data packet flow is presented in this paper. The proposed imitation model was created using the convolution of Moore and Mealy automata.
\end{abstract}

Keywords: batch flow, bursty flow, data traffic, the convolution of Moore and Mealy automata.

\section{Introduction}

For describing of telecommunication systems behavior the various characteristics of data packet flow are important. Therefore it is important to have the analytical models of data packet flows.

The creation of imitation models is possibly the only feasible method for investigation of advanced flows, because the analytical models are fairly complex or in common case they could not be created (in analytical models one is restricted to Poisson distribution).

Usually in practice so called bursty and batch data packet flows are founded. Their structure is presented in Fig 1.

The data packet flow arrives to a telecommunication system on particular time slots in active windows, and input of data packets into system is blocked on the passive windows. Besides, at a fixed time moment several packets can arrive together, i. e. this is a batch flow.

The practical experience showed that the special combination (the convolution) of Moore and Mealy automata can be used effectively in the modeling of telecommunica-

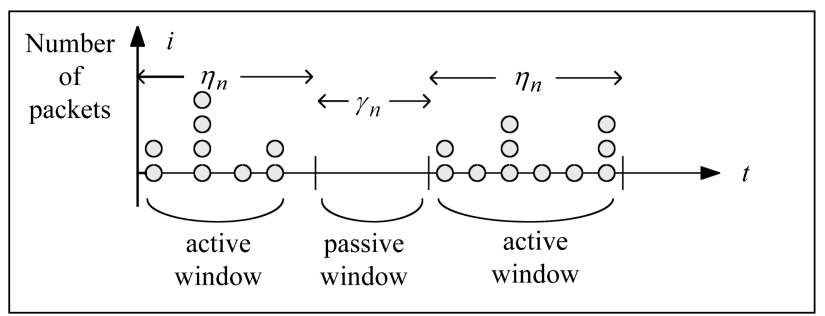

Fig 1. Bursty and batch data packet flow model tion systems [1]. Note, that the events realized in communications have a very simple structure (a packet is started to transmit, a packet is finished to transmit - two types of events occur in the system), so it is not expedient to use the aggregate models for telecommunication systems. Moreover, the imitation models, based on the convolution of Moore and Mealy automata, are implemented easily.

One of the telecommunication systems investigation tasks is to create a handy for user imitation model of bursty and batch data packet flow $[2,3]$. This model's results, processed by the packets of statistical analysis, will be used for further investigation of telecommunication systems. Thus the imitation model of bursty and batch flow is proposed in this paper.

\section{The analytical model of batch data packet flow}

The stationary flow without influence is called the batch Poisson flow, if at least two packets can arrive at one time moment (Fig 2) [4].

The data packets arriving at moments of this flow form

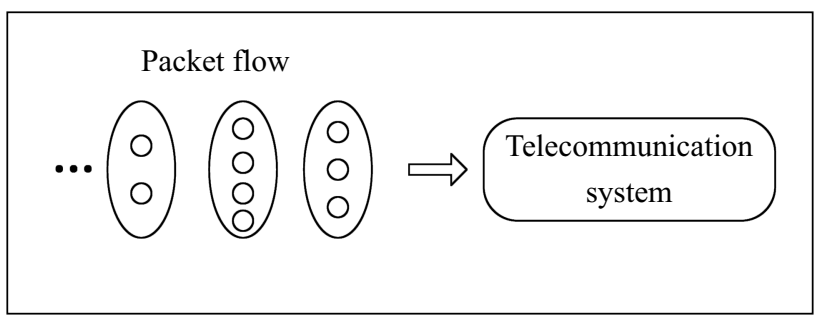

Fig 2. Batch data packet flow model 
the ordinary flow with parameter $\lambda$. Therefore the possibilities of data packet arrival moments in time $t$ are distributed by Poisson distribution. The number of the $l(l=\overline{1, r}, r \leq \infty)$ packets is obtained at every packet arrival moment with probability $p_{l}$. Thus at an $i$-th data packet arrival moment the number $l_{i}$ is called the characteristic of batch $i$-th moment.

Let us say $a_{l}=\lambda p_{l}$ [4]. The probability $P_{k}(t)$ of $k$ packets arrivals during the time $t$ is expressed:

$$
P_{k}(t)=e^{-\lambda t} \sum_{j_{1}, j_{2}, \ldots, j_{r}} \frac{\left(a_{1} t\right)^{j_{1}}}{j_{1} !} \frac{\left(a_{2} t\right)^{j_{2}}}{j_{2} !} \cdots \frac{\left(a_{k} t\right)^{j_{r}}}{j_{r} !},
$$

where the summation is performed by all $j_{1}, j_{2}, \ldots$, $j_{k}=0,1,2, \ldots$, meeting the condition:

$$
k=j_{1}+2 j_{2}+3 j_{3}+\ldots+r j_{r} .
$$

Then the quantity $a_{l}$ can be interpreted as the total intensity of packet flows with $l$ packets at each flow. The parameter of batch flow $\lambda$ and the data packets servicing intensity $\mu$ are accordingly equal:

$$
\begin{gathered}
\lambda=\sum_{l=1}^{r} a_{l}, \quad r \leq \infty, \\
\mu=\sum_{l=1}^{r} \lambda l p_{l}=\sum_{l=1}^{r} l a_{l}, \quad r \leq \infty,
\end{gathered}
$$

here $\mu \geq \lambda$.

This model [4] has not been realized by computer, because the realization of the relation (2) is rather complicated. Therefore having the imitation models it is not expedient to realize (2).

In common case it is impossible to describe the flows without influence by common analytical methods. Therefore it is expedient to imitate such flows and to calculate their characteristics numerically [5].

\section{The creation of imitation models of bursty and batch data packet flow}

Note that nominally describing the teletraffic imitation models two different automata - Moore and Mealy - can be used, because Moore automaton performs an operating function and Mealy automaton performs an implementation function.

We will show how the imitation model of the bursty and batch data packet flow can be described using the convolution of Moore and Mealy automata [1].

The conjunction of Moore and Mealy automata (Fig 3) is called the convolution of Moore and Mealy automata. The following surjections describe the work of this convolution:

$$
\begin{aligned}
& g_{r}: \quad Y \times W \rightarrow W, \quad f_{l}: \quad X \times Z \rightarrow Y, \\
& f_{r}: W \rightarrow X, \quad g_{l}: X \times Z \rightarrow Z,
\end{aligned}
$$

where:

$W$ - the set of states of Moore automaton,

$X$ - the set of output signals of Moore automaton and input signals of Mealy automaton,

$Y$ - the set of output signals of Mealy automaton and input signals of Moore automaton,

$Z$ - the set of states of Mealy automaton.

Besides the convolution of automata starts operating after the initial states $z_{0}$ and $w_{1}$ are introduced. The implementation of the work of automata convolution can be presented as in Fig 4.

Creating the relations system, that describes the working of the convolution of Moore and Mealy automata, we use the closure of the system (i.e. the generation of data packets is treated as the work of servicing device with infinite number of states).

Then the imitational bursty and batch flow schematically can be presented as in Fig 5 .

We will describe the conjunction of three servicing devices (Fig 5), that will generate the bursty and batch data packet flow. The device $A I_{0}$ will generate "the full flow" $\left(\xi_{n}, n=1,2, \ldots\right), A I_{1}-$ active $\left(\eta_{n}, n=1,2, \ldots\right)$ and passive $\left(\gamma_{n}, n=1,2, \ldots\right)$ windows. In $A I_{1}$ device packets arrived from buffers $B_{a}$ and $B_{s}$ are served alternatively. The servicing time of a packet from buffer $B_{a}$ will be a

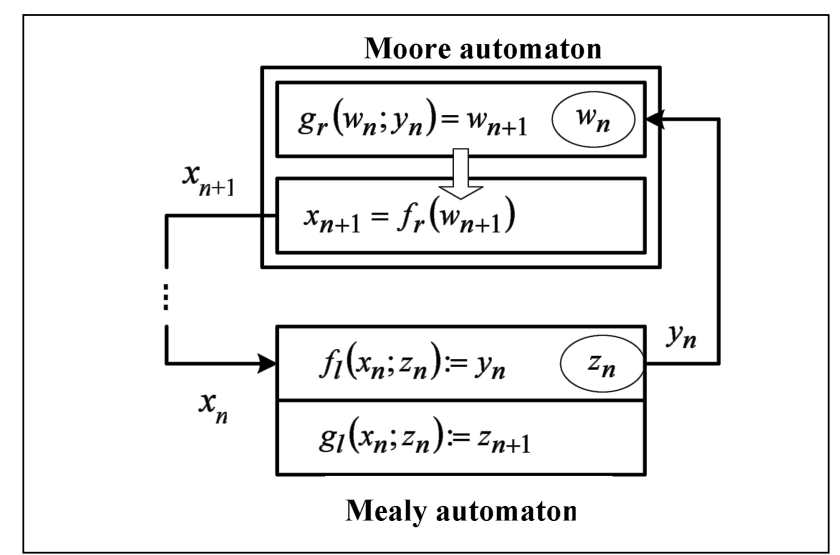

Fig 3. The convolution of Moore and Mealy automata

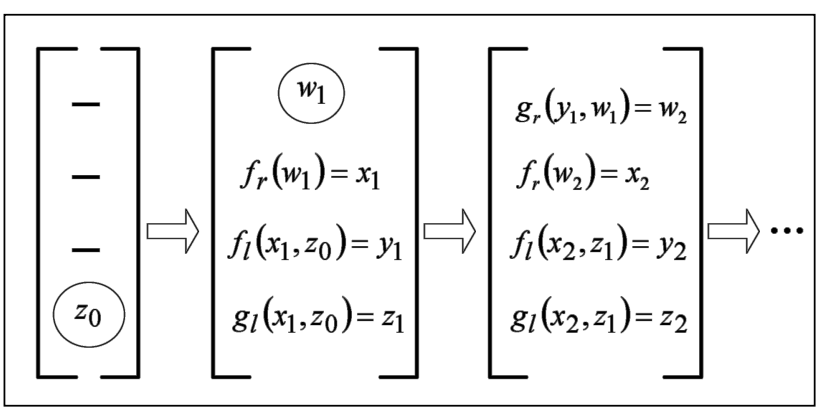

Fig 4. The implementation of the work of automata convolution 


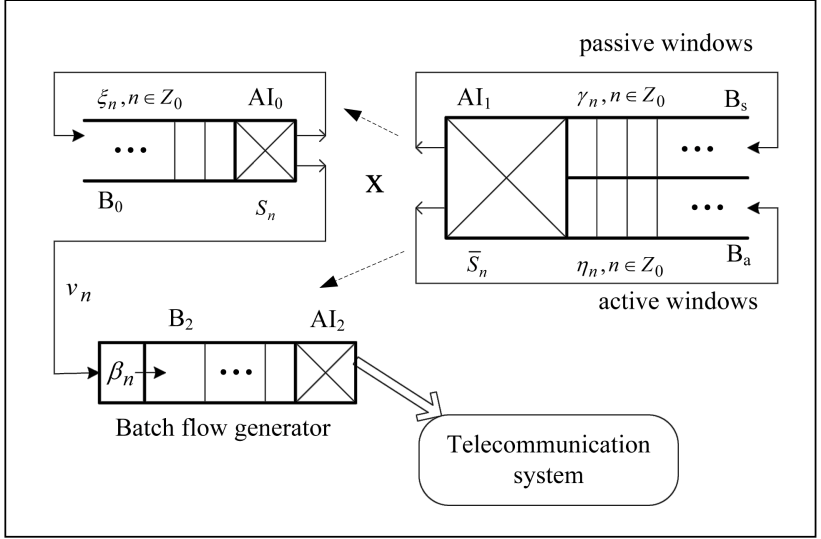

Fig 5. The imitation model of bursty and batch data packet flow

random value $\eta_{n}, n=1,2, \ldots$, together it will be the duration of an active window, and the servicing time of a packet from buffer $B_{s}-\gamma_{n}, n=1,2, \ldots-$ it will be the duration of a passive window. The work of $A I_{1}$ device influences the work of $A I_{0}$ device - when an active window is generated (device $A I_{1}$ serves a packet from buffer $B_{a}$ ), all packets served in $A I_{0}$ device will get into buffer $B_{2}$; when a passive window is generated ( $A I_{1}$ device serves a packet from buffer $B_{S}$ ), packets served in $A I_{0}$ device will get into buffer $B_{0}$. The batch data packet flow will be garnered in the buffer $B_{2}$ of $A I_{2}$ device: the arrived packet is multiplexed into some packets.

Creating the surjections of automata conjunction (Fig 5) we use the variables:

$$
\begin{aligned}
& t_{n}\left(t_{n} \geq 0\right) \text { - "timer"; } \\
& v_{n}, z_{n}, l_{n}, S_{n} \text {-variables of } A I_{0} \text { device; } \\
& \bar{v}_{n}, \bar{z}_{n}, \bar{l}_{n}, \bar{S}_{n} \text { - variables of } A I_{1} \text { device; }
\end{aligned}
$$$$
v_{n}, \bar{v}_{n}-\left(v_{n}, \bar{v}_{n}=0 ; 1\right)-v_{n}=1 \text { denotes the input of }
$$
packet into buffer at time $t_{n} ; v_{n}=0$ - there is no mentioned packet ( $\bar{v}_{n}$ - analogously);

$z_{n}$ - number of packets in buffer $B_{2}$;

$l_{n}, \bar{l}_{n}, n$ - counters;

$S_{n}, \bar{S}_{n}$ - controlling variables defining the interarrival times of packets at servicing devices $\left(S_{n}, \bar{S}_{n} \geq 0\right)$;

$N$ - number of imitational events;

$\xi_{n}, n=1,2, \ldots$ - time slots between arrival moments of neighboring packets of full flow;

$\eta_{n}, n=1,2, \ldots \quad$ - durations of active windows;

$\gamma_{n}, n=1,2, \ldots-$ durations of passive windows;

$\alpha_{n}, n=1,2, \ldots-$ random values, uniformly distributed in interval $(0,1)$, defining the characteristic of batch;

$\beta_{n}$ - number of packets arrived into servicing system at the same time (the result of multiplexing).
Logical units:

$$
\mathbf{1}(t):=\left\{\begin{array}{ll}
0 & t<0 \\
1 & t \geq 0
\end{array}, \quad \overline{\mathbf{1}}(t):=\left\{\begin{array}{ll}
0 & t \leq 0 \\
1 & t>0
\end{array} .\right.\right.
$$

The auxiliary random quantities are needed:

$$
\begin{aligned}
& \xi_{0}:=0, \quad\left(\xi_{n} ; n=1,2, \ldots\right), \\
& \eta_{0}:=0, \quad\left(\eta_{n} ; n=1,2, \ldots\right), \\
& \gamma_{0}:=0, \quad\left(\gamma_{n} ; n=1,2, \ldots\right) .
\end{aligned}
$$

Then the state of Mealy automaton is described by such vector:

$$
Z=\left\{z_{n} \mid n=0,1,2, \ldots\right\} .
$$

The state of Moore automaton:

$$
w_{n}:=\left(n ; l_{n} ; \bar{l}_{n} ;\left(S_{n}, \bar{S}_{n}\right)\right) ;
$$

the output signal from Moore automaton is an input signal for Mealy automaton:

$$
x_{n}=\left(n, t_{n},\left(v_{n}, l_{n} ; \bar{v}_{n}, \bar{l}_{n}\right)\right), x_{n} \in X ;
$$

the output signal from Mealy automaton is an input signal for Moore automaton:

$$
y_{n}=x_{n}, y_{n} \in Y .
$$

The initial conditions:

$$
z_{0}:=0, \quad S_{1}:=\xi_{1}, \bar{S}_{1}:=\eta_{1} ;
$$

counters:

$$
n:=1, \quad l_{1}:=1, \quad \bar{l}_{1}:=1
$$

the probabilistic constants:

$$
q_{0}:=0, \quad q_{r}:=\sum_{m=1}^{r} p_{m}, \quad r=1,2, \ldots, K .
$$

It is given that $K=1,2, \ldots$ and the probabilities $p_{r}>0$, when $p_{1}+p_{2}+\ldots+p_{k}=1, q_{K}=1$.

Then corresponding surjections $g_{r}, f_{r}, f_{l}, g_{l}$ will be denoted as follows:

- We will create a surjection $f_{r}: W \rightarrow X$, i. e. $f_{r}\left(w_{n}\right)=x_{n}$. At first the "present" time is fixed:

$$
t_{n}:=\min \left(S_{n}, \bar{S}_{n}\right),
$$

and the moments of the packets service end:

$$
\begin{aligned}
& v_{n}:=1\left(t_{n}-S_{n}\right), \\
& \bar{v}_{n}:=1\left(t_{n}-\bar{S}_{n}\right) .
\end{aligned}
$$

Counters (defining which value $\xi, \eta$ shall be taken from sequence): 


$$
l_{n}:=l_{n}+v_{n}, \bar{l}_{n}:=\bar{l}_{n}+\bar{v}_{n} .
$$

The output - input signal

$$
x_{n}=\left(n, t_{n},\left(v_{n}, l_{n} ; \bar{v}_{n}, \bar{l}_{n}\right)\right)
$$

is formed.

- Then a surjection $f_{l}: X \rightarrow Y$, i.e. $f_{l}\left(x_{n}\right)=y_{n}$, is created. In this model:

$$
y_{n}=x_{n} .
$$

- Creating a surjection $g_{l}: X \times Z \rightarrow Z$, i.e. $g_{l}\left(x_{n}, z_{n-1}\right)=z_{n}$, the additional variable $\beta_{n}$ (the multiplexer) is required, that denotes the number of packets, arrived into servicing device at the same moment:

$$
\beta_{n}:=v_{n} \sum_{m=1}^{K} m \cdot \mathbf{1}\left(q_{m}-\alpha_{l_{n}}\right) \cdot \overline{\mathbf{1}}\left(\alpha_{l_{n}}-q_{m-1}\right) .
$$

After that the total number of packets of batch flow in buffer is calculated:

$$
z_{n}:=z_{n-1}+\frac{1}{2}\left(1-(-1)^{\bar{l}_{n}}\right) \beta_{n} .
$$

- Creating the last surjection $g_{r}: W \times Y \rightarrow W$, i.e. $g_{r}\left(w_{n}, y_{n}\right)=w_{n+1}$, the moments of events are fixed:

$$
S_{n+1}:=S_{n}+v_{n} \xi_{l_{n}}
$$

and

$$
\bar{S}_{n+1}:=\bar{S}_{n}+\bar{v}_{n}\left(\eta_{a}+\gamma_{b}\right),
$$

where

$$
\begin{gathered}
a=\left(\bar{l}_{n}+1\right) \frac{1+(-1)^{\bar{l}_{n}+1}}{4}, \\
b=\bar{l}_{n} \frac{1+(-1)^{\bar{l}_{n}}}{4} .
\end{gathered}
$$

Note that $a \neq 0$ when an active window is operating, $b \neq 0-$ when the passive window is operating. The state of Moore automaton $w_{n}:=\left(n ; l_{n} ; \bar{l}_{n} ;\left(S_{n}, \bar{S}_{n}\right)\right)$ is formed.

Formulas $(23,26,27,28)$ are original and other formulas (17-22, 24-25) are typical.

Thus the digital implementation of Moore and Mealy automata can be such as in Fig 6.

Presented algorithm imitates a bursty data packet flow, so if we want to get the algorithm (Fig 6) of simplified no bursty data packet flow (thus saving the time resources of computer), the algorithm must be modified as shown in Fig 7.

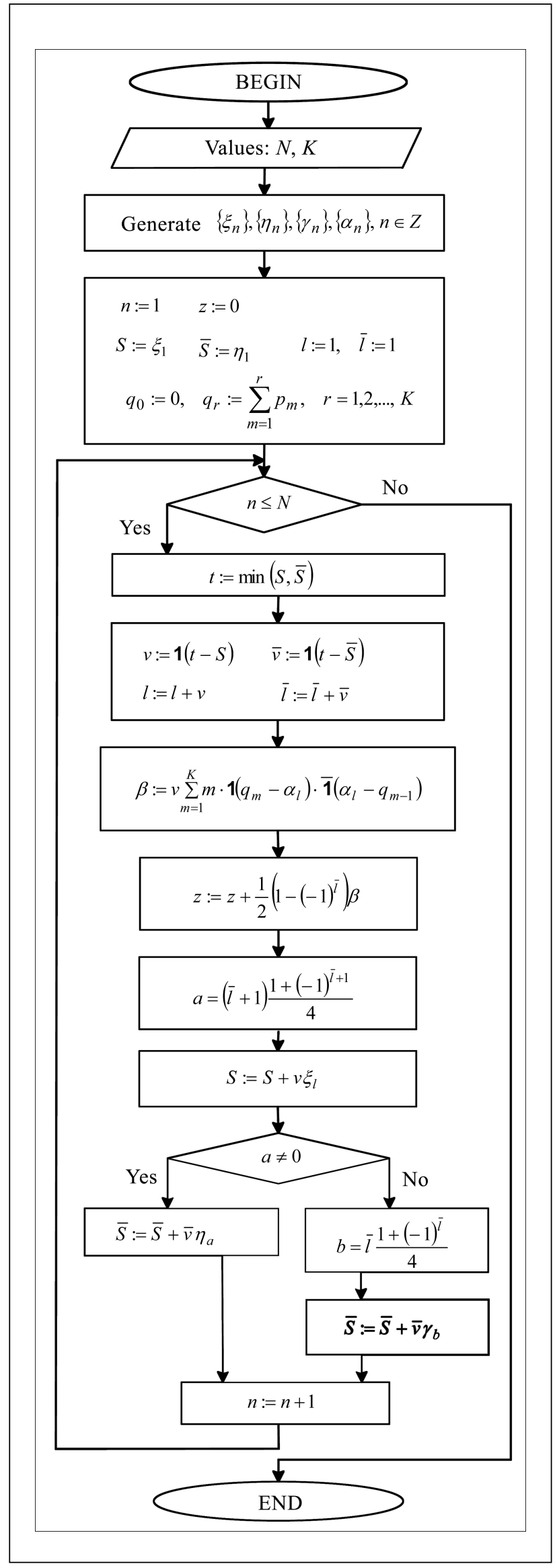

Fig 6. The algorithm of imitation model of bursty and batch data packet flow 


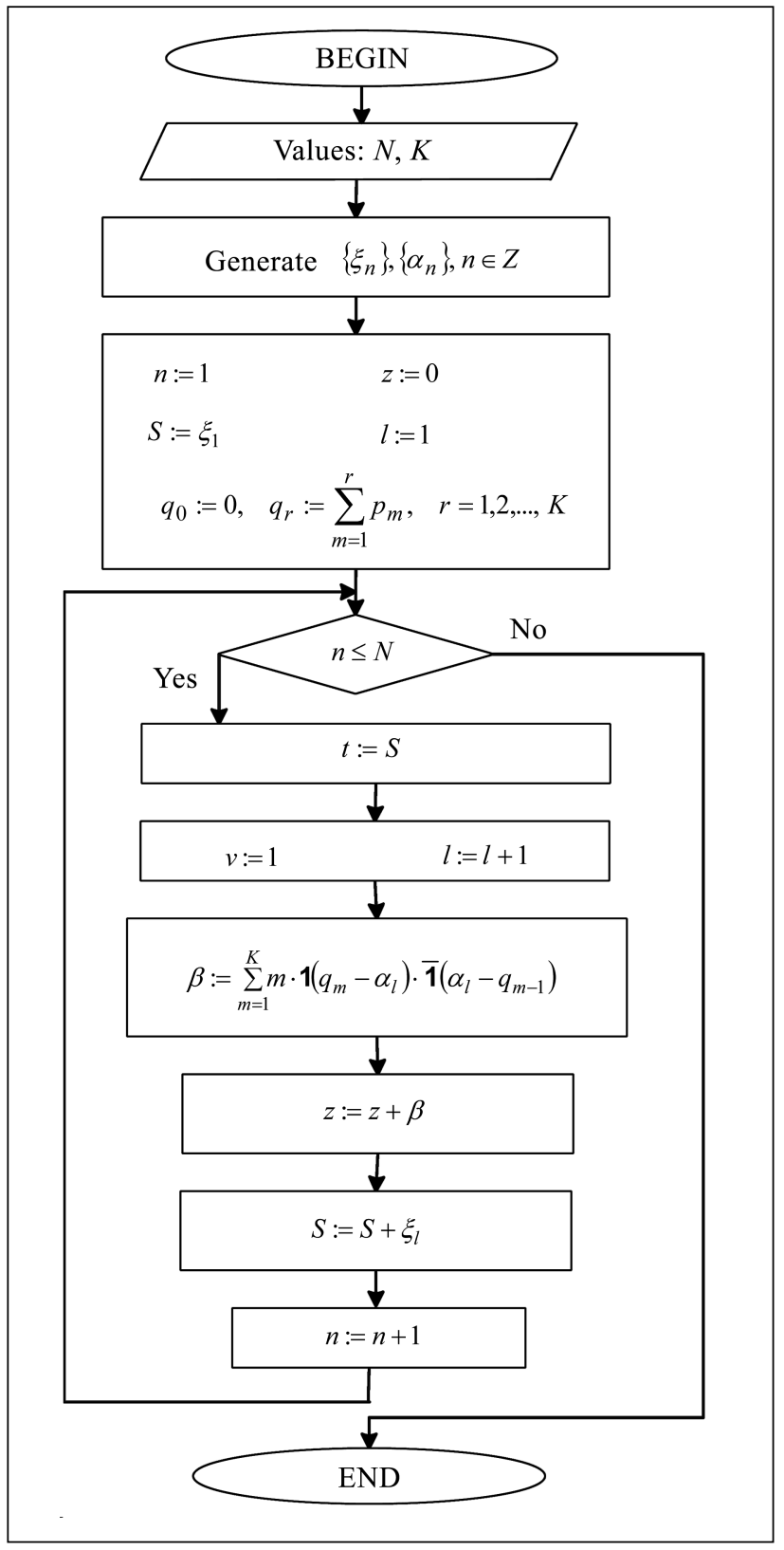

Fig 7. The algorithm of imitation model of no bursty data packet flow

Besides, creating the calculation algorithm the variables, that do not influence calculation algorithm, were eliminated.

The results of imitation model of no bursty data packet flow (29) were obtained during imitation process.

$$
\left[\begin{array}{l}
0 \\
0 \\
0
\end{array}\right],\left[\begin{array}{c}
1 \\
t_{1} \\
z_{1}
\end{array}\right],\left[\begin{array}{c}
2 \\
t_{2} \\
z_{2}
\end{array}\right], \ldots,\left[\begin{array}{c}
n \\
t_{n} \\
z_{n}
\end{array}\right], \ldots,\left[\begin{array}{c}
N \\
t_{N} \\
z_{N}
\end{array}\right] .
$$

The found implementation is processed. The sequences $\left(I_{n, k} ; n=0,1,2, \ldots\right)_{k} \quad k=1,2, \ldots$ are created:

$$
I_{n, k}:=\left(z_{n+k}-z_{n} ; t_{n+k}-t_{n}\right) .
$$

It means, that: during time $t_{n+k}-t_{n}$ packets $z_{n+k}-z_{n}$ arrive, i.e. $P(X \in\{0,1,2, \ldots\})=1$ of two-dimensional random variables $(T, X)$, when $P(T \geq 0)=1$.

In [4] the investigations were accomplished only with exponential data flows. This model lets modeling of the bursty and batch packet flow using various probabilistic distributions or their combinations, accordingly choosing the parameters of distributions and the parameters for input flows.

\section{Implementation details}

We present some simulation results of bursty and batch data packet flows (figures 8-11) from the imitation model.

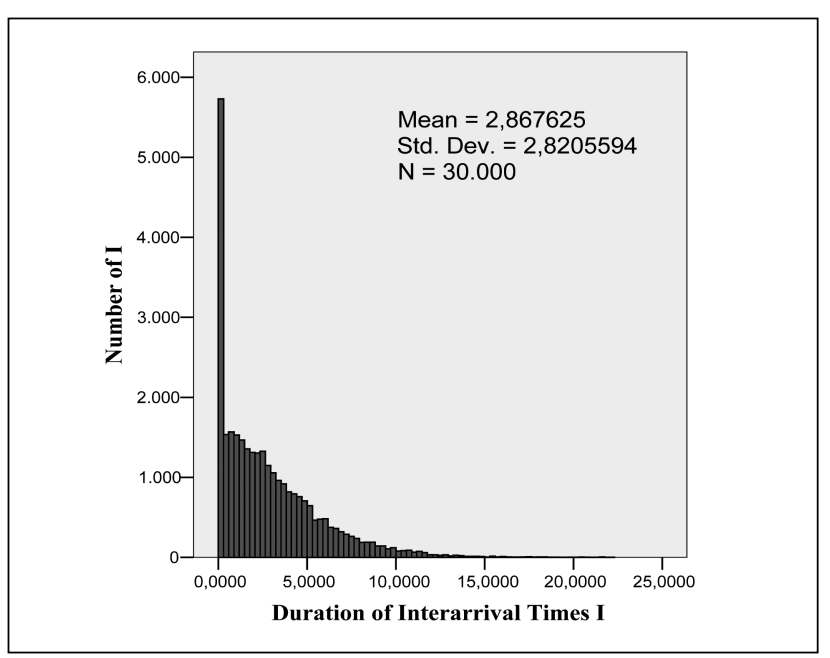

Fig 8. Histogram of interarrival times, when input flow Poisson with parameter $\lambda=2$ and with active windows - Exponential with parameter $\lambda=2$ and passive windows - Exponential with parameter $\lambda=8$

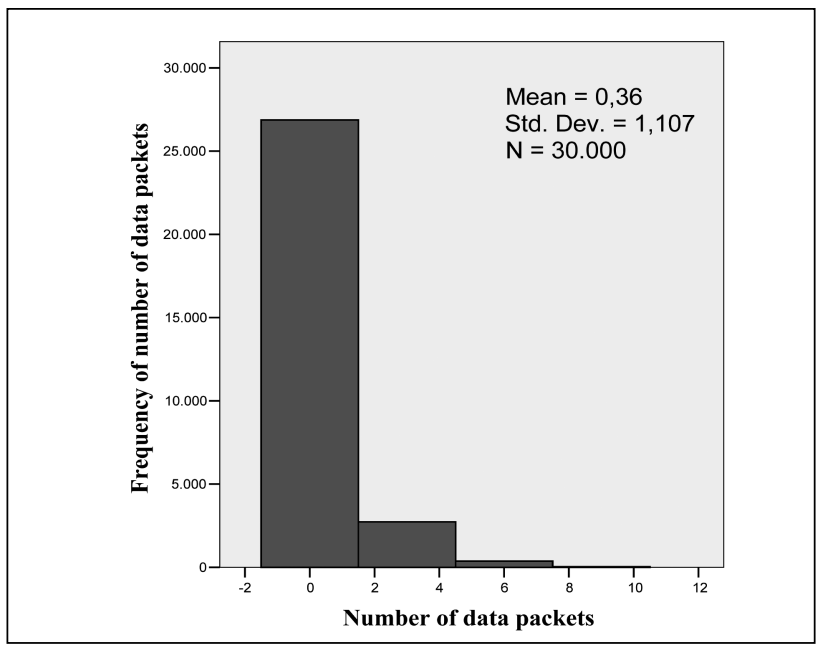

Fig 9. Histogram of number of data packets, when input flow Poisson with parameter $\lambda=2$ and with active windows - Exponential with parameter $\lambda=2$ and passive windows - Exponential with parameter $\lambda=8$ 


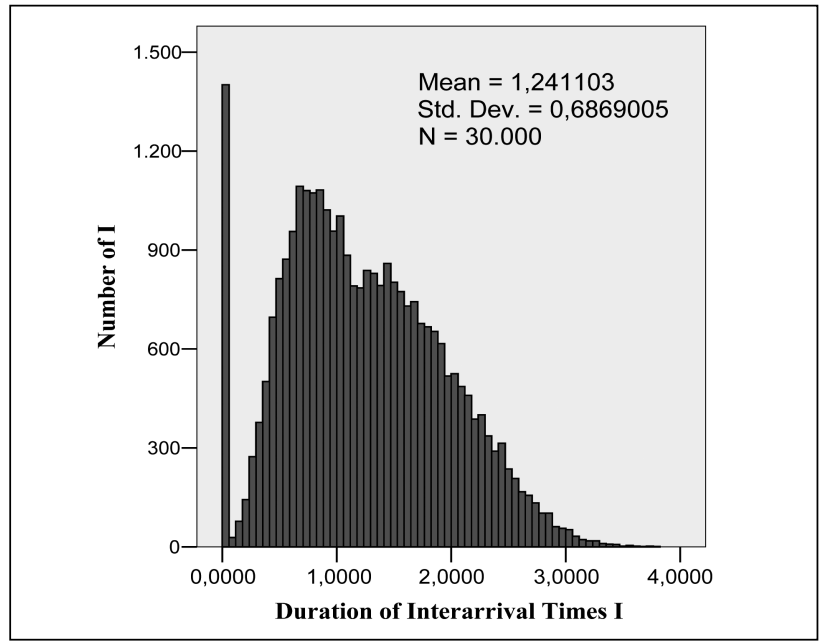

Fig 10. Histogram of interarrival times, when input flow Weibull with parameters $a=2, s=3$ and with active windows - Exponential with parameter $\lambda=2$ and passive windows - Exponential with parameter $\lambda=8$

We got many flows, which have not been recognized by the packets of statistical analysis SPSS, Statgraphics. The experiments showed that in the common case the flow is not exponential, so it is expedient to investigate this flow.

Executing the simulation statistical researches with programs SPSS, Statgraphics and establishing the flow parameters we may successfully apply the proposed model for the performance analysis of telecommunication networks.

\section{Conclusions}

Real data packet traffic is usually more bursty than Poisson or Markovian traffic, therefore it cannot be adequately modeled by Poisson or Markovian models.

The generation methodology of the bursty and batch data packet flow generated by one source has been created using the special combination of convolution of Moore and Mealy automata. The experiments showed that this flow significantly differs from "the full flow" by its properties.

Choosing the distributions of random values $\xi_{n}, \eta_{n}, \gamma_{n}$ the various bursty and batch data packet flows can be obtained and later their characteristics can be investigated.

The proposed model has possibility to offer no bursty

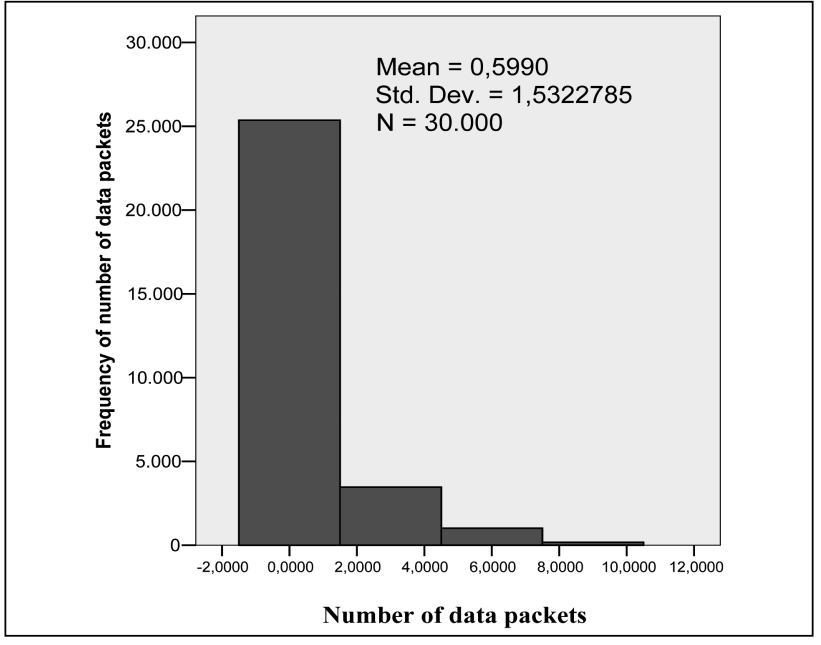

Fig 11. Histogram of number of data packets, when input flow Weibull with parameters $a=2, s=3$ and with active windows Exponential with parameter $\lambda=2$ and passive windows - Exponential with parameter $\lambda=8$

data packet flow, if $\eta_{1}=\operatorname{Inf}$ (there will be no passive windows).

Using this model we can get the ordinary packet flow as well, if $\beta_{n}=1$.

The burstiness of data flow meets buffering requirements.

\section{References}

1. Žvironiene, A.; Navickas, Z.; Rindzevičius, R. The expression of the Telecommunication system with an infinite queue by the convolution of Moore and Mealy automata, ITI 2005. In: ISI Proceedings of the 27th International Conference on Information Technology Interfaces, Cavtat, Croatia, 2005, p. 669-672. ISBN 953-7138-02-X.

2. Heng-Qing Ye, Jihong Ou, Xue-Ming Yuan. Stability of Data Networks: Stationary and Bursty Models. Operating Research, 53, No 1, 2005, p. 107-125.

3. Hao Jiang, Constantinos Dovrolis. The effect of low capacities on the burstiness of aggregated traffic. Operating Research, 68, No 3, 2006, p. 85-105.

4. Корнышев, Ю. Н.; Фаль, Г. Л. Теория распределения информации. Москва: Радио и связь, 1985, с. 22-23.

5. Flaus, J. H. ; Thevenon, L. Data flow modeling for batch and hybrid processes. ISA Trans, 42(3), 2003, p. 361-380.

\section{NEORDINARINIO PLIŪPSNINIO PARAIŠKŲ SRAUTO IMITACINIS MODELIS}

\section{A. Žvironienė, Z. Navickas, R. Rindzevičius}

S a n tra u k a

Telekomunikacinių sistemų sėkmingam funkcionavimo aprašymui ypač daug reikšmės turi ịvairios duomenų srautų charakteristikos. Todẻl aktualu turèti minètų srautų analizines išraiškas. Kadangi analiziniai modeliai arba yra ganètinai sudètingi, arba iš viso jų neįmanoma bendresniu atveju sudaryti, tai imitacinis modeliavimas galbūt vienintelis įmanomas sudètingesnių srautų tyrimo metodas. 
Vienas iš telekomunikacinių sistemu tyrimo uždavinių - turèti patogų vartotojui neordinarinio pliūpsninio srauto imitacini modeli, kad, gautas duomenų imtis apdorojus statistiniais paketais, būtų galima naudoti toliau tirti telekomunikacines sistemas. Taigi straipsnyje pasiūlytas neordinarinio pliūpsninio paraiškų srauto imitacinis modelis, sudarytas naudojant Muro ir Milio automatų sąsūką.

Reikšminiai žodžiai: neordinarinis srautas, pliūpsninis srautas, duomenų srautas, Milio ir Muro automatų sąsūka.

Aušra ŽVIRONIENĖ. Master of mathematics, an assistant in the Department of Applied Mathematics of Kaunas University of Technology. She published 14 research papers in modeling of telecommunication systems using finite automata and other methods.

Zenonas NAVICKAS. Professor in the Department of Applied Mathematics of Kaunas University of Technology, Doctor of mathematic sciences of Vilnius University. He had participated in an internship at Kalinin University in Russia in 1984. He was a junior Professor in Institute of Light Industry in Algeria in 1977-1980. He is an author of two books, published over hundred research papers in operator calculus, differential equations and modeling of telecommunication systems using finite automata. The field of research - the theory of automata, operator calculus, differential equations.

Ramutis RINDZEVIČIUS. Associated Professor in the Department of Telecommunications of Kaunas University of Technology, Doctor of Electrical and Electronics engineering of Kaunas University of Technology. The internship took place at Kopenhagen Ericsson training courses in 1994 and at Moscow Electrotechnics Institute of Telecommunications in 1974, 1984. He published about 70 papers and three handbooks. The field of research - analysis of telecommunication systems by means of simulation and analytic models. 